\title{
The Attitudinal and Behavioral Effects of Nonfinancial Measures
}

\author{
Putri Paramita Agritansia \\ Faculty of Economics and Business, Universitas Gadjah Mada
}

Mahfud Sholihin

Accounting Department, Faculty of Economics and Business, Universitas Gadjah Mada

\begin{abstract}
A recent study by Lau and Moser (2008) found that the use of nonfinancial measures for managerial performance evaluation is positively associated with managerial performance via procedural fairness and organizational commitment. It is not clear, however, whether the findings are generalizable to other contexts. Using very different samples, the objectives of this study are to reexamine and to extend Lau and Moser's model. Our paper is only able to partially support their model, suggesting that management control systems should be designed to fit the contexts.
\end{abstract}

Abstrak: Hasil penelitian Lau dan Moser (2008) menemukan bahwa penggunaan ukuran-ukuran nonfinansial untuk mengevaluasi kinerja manajerial berhubungan positif dengan kinerja manajerial melalui keadilan prosedural dan komitmen organisasional. Meski demikian, tidak ada kejelasan apakah temuan mereka bisa digeneralisasi dalam konteks lain. Menggunakan sampel yang sangat berbeda, tujuan dari penelitian ini adalah untuk menguji kembali dan memperluas model Lau dan Moser. Penelitian kami hanya mampu memberikan dukungan sebagian atas model yang mereka ajukan. Temuan kami menunjukkan bahwa sistem pengendalian manajemen harus didesain agar sesuai dengan konteks.

Keywords: interpersonal trust; managerial performance; nonfinancial measures; organizational commitment; procedural fairness 


\section{Introduction}

This paper aims to examine the attitudinal and behavioral consequences of the use of nonfinancial measures in managerial performance evaluation. Whilst the literature suggests that companies should implement nonfinancial measures to complement financial measures (e.g. Kaplan and Norton 1996), there is a lack of empirical confidence on the effect of nonfinancial measures on subordinate managers' attitudes and behavior. ${ }^{1}$ Among the rare studies is the one conducted by Lau and Moser (2008)-hereafter referred to as $\mathrm{L} \& \mathrm{M}$.

$\mathrm{L} \& \mathrm{M}$ examined whether the use of nonfinancial measures affects managerial performance and whether such effect is mediated by procedural fairness and organizational commitment. Their model is depicted in Figure 1. Using samples of senior managers of manufacturing companies in the UK, they found that the use of nonfinancial measures positively affects managerial performance via procedural fairness and organizational commitment.

Whilst the study of $L \& M$ has advanced our understanding on the attitudinal and behavioral effects of nonfinancial measures, there are some issues that merit further investigation which will be addressed by this paper. First, whilst L\& M use senior managers of manufacturing companies in the UK, it is not clear whether their findings are generalizable into other contexts such as different countries and managerial levels. The first objective of this paper is to replicate and to test the external validity of their study using very different samples. In doing so, this current study uses samples derived from Indonesian managers at lower and medium managerial levels. This type of study is important as emphasized by Lindsay and Ehrenberg (1993), "It (replication) is needed not merely to validate one's findings, but more importantly, to establish the increasing range of radically different conditions under which the findings hold, and the predictable exceptions"

\section{Figure 1. Lau and Moser's (2008) Model}

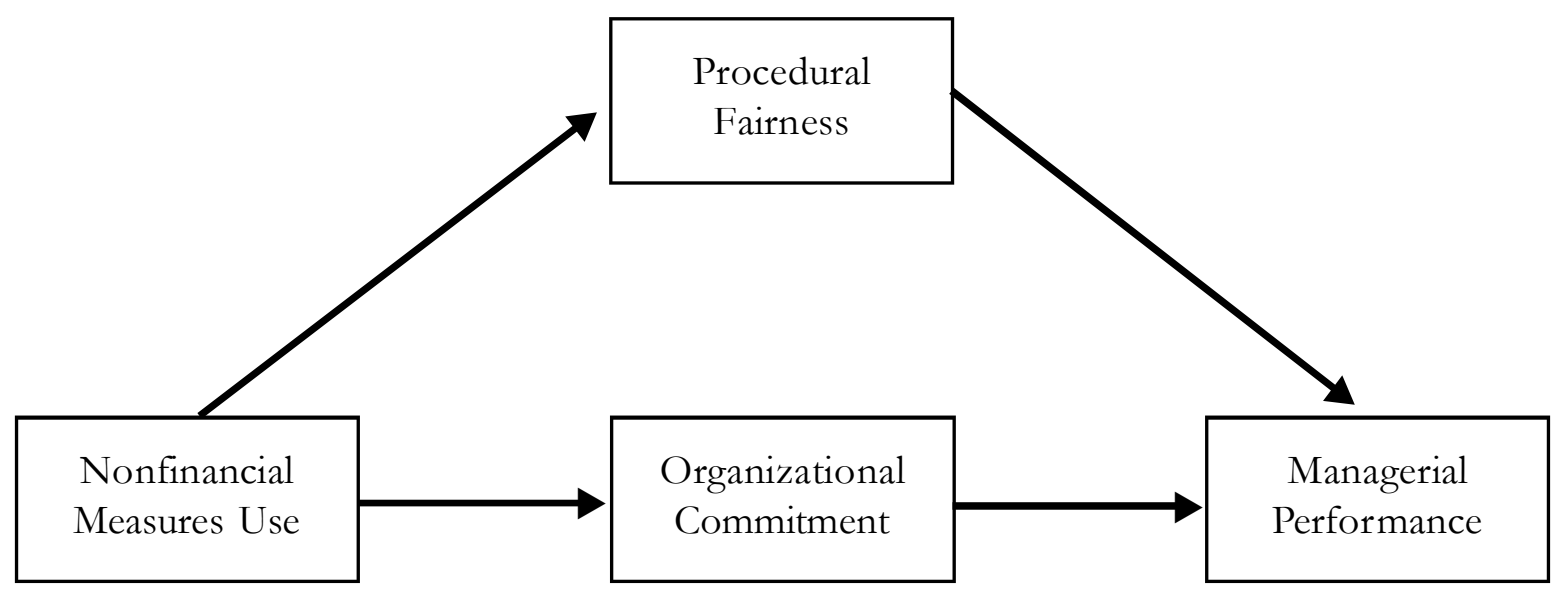

${ }^{1}$ In contrast, there are a lot of studies devoted to the effects of financial (accounting) performance measures on subordinate managers' attitudes and behavior [for review, see for example, Briers and Hirst (1990), Hartmann (2000), and Noeverman et al. (2005)]. 
(p. 217, parentheses added). Particular to the role of procedural justice, ${ }^{2}$ Leung (2005) calls for researchers to examine procedural fairness development in various contexts and notes that "a universal concern of justice... does not mean that all justice effects are necessarily generalizable ...” (p. 557). We use Indonesian managers as our sample because whilst a substantial number of Indonesian companies implement nonfinancial measures, such as the ones contained in the Balanced Scorecard (Supriyadi 2010), there is a lack of systematic studies on the attitudinal and behavioral effects of nonfinancial mesures (Lau and Sholihin 2005).

Secondly, in analyzing their structural model, with 149 samples, L\&M have used AMOS. Bacon (1997) stated that to properly utilize AMOS, a study has to have 200 samples at the minimum. Consequently, we reexamine L \& M's model using Partial Least Square (PLS) with SmartPLS version. 2.0 soft- ware. We used PLS as this approach is able to handle small samples(Wold 1982; Wold et al. 1987).

Thirdly, since previous accounting studies (e.g. Lau and Sholihin 2005) found that nonfinancial measures is associated with trust and trust is associated with organizational commitment (Sholihin and Pike 2009) and with managerial performance (Sholihin et al. 2004), this study examines if trust mediates: (1) the relationship between nonfinancial measures and managerial performance; and (2) the relationship between organizational commitment and managerial performance. Hence, this study does not merely replicate the $\mathrm{L} \& \mathrm{M}$ study, but it also extends their study. The model for our study is portrayed in Figure 2.

Our study partially supports L \& M because we do not find the positive association between nonfinancial measures and procedural fairness. Using the extended model, we

Figure 2. Model of Our Study

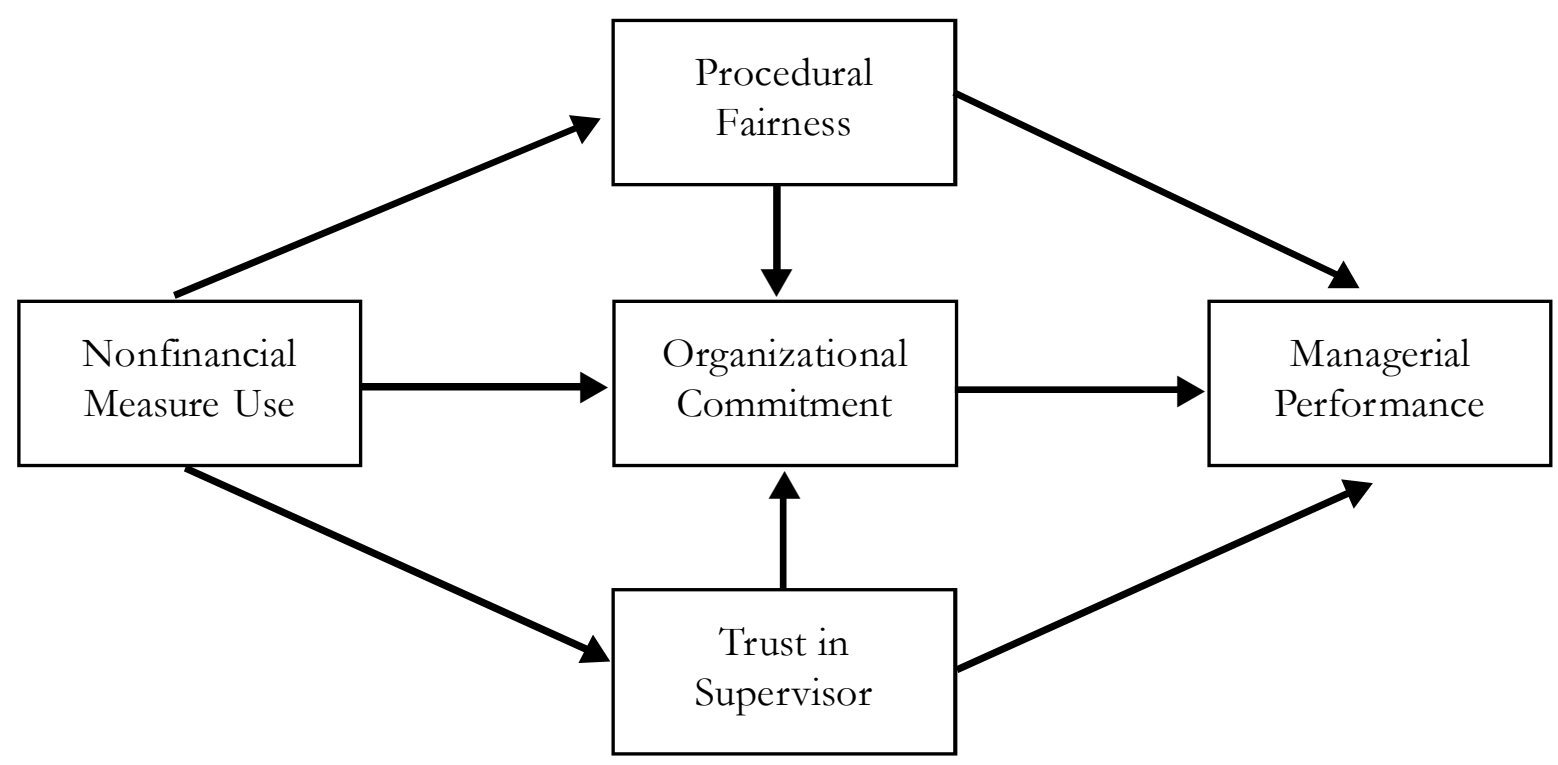

${ }^{2}$ We use the terms procedural justice and procedural fairness interchangeably. 
do not find a positive association between nonfinancial measures and trust.

The rest of the paper is organized as follows. The next section will discuss the literature review and hypotheses development. This will be followed by a presentation of the research method, research findings, conclusions, limitations, and suggestions for future research.

\section{Literature Review and Hypotheses Development}

\section{Nonfinancial Measures and Procedural Fairness}

The implementation of performance measurement systems, argued by Ittner and Larcker (1998), substantially support organizations in committing strategic plans, evaluating goals attainment, and formulating managerial compensation plans. Merchant (2006) emphasizes that performance measures play a key role in raising managers' motivation to meet organization goals by combining goals attainment and various incentives in managerial performance evaluation systems.

Considering the limitatons of financial measures alone, Kaplan (1996) and some other researchers promote the implementation of nonfinancial measures such as product innovation, product leadership, and customer loyalty. These relatively new measures are believed to be better at indicating organization future profitability than annual profit. Vaivio (1999) contends that "Non-financial measures could provide more penetrating control, going beyond the limits of aggregated financial measurements" (p. 410). Furthermore, Kaplan and Norton (1996a) mention that nonfinancial measures may perform as primary indicators towards an organization's future performance and create a synergy among long-term organizational objectives. In addition, Ittner and Larcker (2000) suggest nonfinancial measures may also provide indirect quantitative information on a company's intangible assets, improve managers' performance through transparent evaluation systems and in particular present significant indicators related to an organization's future financial performance.

This paper argues that the use of nonfinancial measures for managerial organization performance evaluation enables superiors to evaluate subordinates by using multiple diverse perspectives that may enhance subordinates' perception of procedural fairness. With reference to Viavio's (1999) contention, we may conclude that the use of nonfinancial measures in evaluating managerial performance may be perceived as a fair process compared to the use of financial measures. For example, due to the process and nature of the work of research and development department mostly taking some time to show desirable progress which often cannot be well reflected in financial terms, if subordinates are evaluated using financial measures they will perceive such an evaluation process to be unfair. In contrast, performance evaluation systems that are implemented by considering the nature and process at the research and development department will make subordinates think that the evaluation process is fair. Empirically, Lau and Sholihin (2005) and L\&M found the implementation of nonfinancial measures is positively associated with procedural fairness. Therefore, the following hypothesis is to be tested:

\section{Ha1: The use of nonfinancial measures in perfor- mance evaluation is positively associated with procedural fairness.}




\section{Procedural Fairness and Managerial Performance}

The term procedural fairness is commonly associated with Thibaut and Walker's (1975) study on procedural justice. In their work, they put different evaluation system approaches specifically on the process control and outcome. Based on the work of Thibaut and Walker (1975), Lind and Tyler (1988) observe that there are three significant findings of Thibaut and Walker (1975): (1) perceptions of procedural justice result in increased satisfaction; (2) procedural justice is the most important determinant of procedural preferences; and (3) high process control procedures lead to high procedural justice judgments. In this regard, by comparing the term of procedural justice and fairness, we believe that besides there being significant concept similarities between procedural justice and fairness, procedural fairness itself may have been triggered by the innovation of procedural justice. Therefore, we maintain the usage of the term procedural justice into procedural fairness in order to not mislead and extend the term of procedural justice itself.

As the term procedural fairness may cover a wide range of concepts, in this study we focus procedural fairness on managers' perceptions with respect to all aspects of fairness in the organizational processes that are used by superiors to evaluate managers' performance, communicate performance feedback and determine their rewards such as promotion and pay increases (Folger and Konovsky 1989). Expectancy theory suggests that better subordinates' performance may be driven by their belief that the measurement evaluation procedures are fair (Vroom 1964; Porter and Lawler 1968). Additionally, since previous studies found that procedural fair- ness affects managerial performance in various contexts (Lind and Tyler 1988; Libby 1999; Libby 2001; Wentzel 2002; Little et al. 2002), thus, we propose that procedural fairness is positively associated with managerial performance in many ways that may motivate subordinates to improve their working performances. Therefore, the following hypothesis is to be tested:

\section{$H_{a 2}:$ Procedural fairness is positively associated with managerial performance}

\section{Nonfinancial Measures and Organizational Commitment}

Porter et al. (1974: 604) define organizational commitment as "the relative strength of an individual's identification with and involvement in a particular organization". Mathieu and Zajac (1990) view organizational commitment as the bond that links an individual to his/her organization. Some reviews (e.g. Mathieu and Jajac 1990; Randall 1990) mentioned that organizational commitment may be conceptualized in various ways. Meyer et al. (1990) identified two types of organizational commitment: affective commitment and continuance commitment. Affective commitment is characterized by a strong belief in and acceptance of organizational goals and values, and a willingness to exert considerable effort on behalf of the organization (Porter et al. 1974; Angle and Perry 1981); while continuance commitment refers to the perceived costs associated with leaving the organization, such as loss of benefits and seniority (Becker 1960). Consistent with previous accounting studies (e.g. Nouri and Parker 1994, 1996, 1998; Chong and Eggleton 2007) we conceptualize organizational commitment as affective organizational commitment. 
Following L \& M, we hypothesize that the use of nonfinancial measures is positively associated with organizational commitment. This is because the nature of nonfinancial measures is capable of capturing managers' performance from a wide range of perspectives. "Managers evaluated by such measures are likely to harbor favorable organizational attitudes, including their commitment to the organization which uses such measures" (L \& M: 58). Therefore we hypothesize as follows:

$H_{a 3}:$ Nonfinancial measures use is positively associated with organizational commitment.

\section{Organizational Commitment and Managerial Performance}

As previously stated, we specify organizational commitment in this study as affective organizational commitment. Established by emotional attachment towards the organization, affective commitment may escort employees' willingness to not only remain in the organization but also to accelerate their working performance (Demir et al. 2009). To better indicate the rising emotional attachment to the organization, Mowday et al. (1982) suggested three characteristics of organizational commitment: identification (belief in and the acceptance of organizational goals and values), involvement (willingness to exert effort on behalf of the organization), and loyalty (strong desire to maintain membership of the organization). By having those characteristics, managers with strong organizational commitment will show active involvement in, and contribution to, the organization. Driven by their emotional attachment, managers will also indicate the intention to work beyond what they are supposed to do. Supported by a number of empirical studies in the accounting literature (e.g. Nouri and Parker 1998; Chong and Eggleton 2007) that found organizational commitment is associated with managerial performance, this study hypothesizes that :

\section{$H_{a 4}$ : Organizational commitment is positively asso- ciated with performance.}

\section{Nonfinancial Measures and Trust}

As the concept of trust varies widely, we based our study on previous accounting studies (e.g. Hopwood 1972; Otley 1978; Ross 1994; Lau and Sholihin 2005) by focusing on trust as interpersonal trust. According to Read (1962), subordinates' interpersonal trust is a "subordinate's trust or confidence in the superior's motives and intentions with respect to matters relevant to the subordinate's career and status in the organization." Whitener et al. (1998) argue that both performance evaluation and incentive systems can affect managerial attitude that may influence subordinates' trust towards their superiors. At this stage, Zand (1997) supports Whitener et al. (1998) only if the incentive system is collaborative, integrative and benefits both parties. Therefore, it is significant for organizations to design their performance evaluation systems so that they are able to facilitate the enhancement of subordinates' trust towards their superiors.

Moreover, the capability of nonfinancial measures in reviewing subordinates from a wide range of perspectives are believed to exert performance evaluation system in enhancing subordinates' trust in their superiors for reasons as follows. First, realizing the possibility of the presence of particular unsatisfying short term financial, quantitative measures during the employment of a performance evaluation system, Kaplan (1983), Johnson and Kaplan (1991) suggested the utilization of a long-term qualitative, nonfinan- 
cial measures. It is believed that the qualitative measures are capable of triggering desirable performances by subordinates that may assist the success of the organization. Once the qualitative measures are precisely evaluated and reflect the nature of the organization or, to be specific, the unit or department subordinates are involved in, subordinates will likely put more reliance on their superiors.

Secondly, evaluating subordinates based on short-term financial, quantitative measures may decipherable as the inability of management in conceiving the various aspects of both subordinates and organization properly. On the other hand, superiors who based their evaluation on long-term, nonfinancial perspectives tend to receive higher subordinates' respect and trust regarding her/his acceptable understanding in carrying out performance evaluation systems. Thus, subordinates may view superiors as having reliable managerial attitude (Mayer et al. 1995).

Thirdly, as indicated by the utilization of multiple nonfinancial measures, subordinates may label superiors as having a profound interest on the organization and subordinates since the exertion of varied nonfinancial measures may "...reflect the complexities of the work environment and (consider) the variety of contributions that employees make" (Atkinson et al. 2001: 407) (parenthesis added). Therefore, it enables a subordinate to not only be labeled as a poor or good performer based on one indicator that is used on a pro rata basis, but they may be beneficially evaluated based on multiple factors, which in part may indicate their various target achievements (Lipe and Salterio 2002). In turn, such conditions may reduce subordinates' career insecurity. In addition, subordinates are likely to view their superiors as having a benevolent attitude in evaluating subordinates' performance. Referring to Whitener et al. (1998), together with the rising subordinates' perception of benevolence, subordinates' awareness of superiors' reliability will also rising. The more reliable the superiors seem to their subordinates, simultaneously, the more subordinates will have a propensity to trust their superiors (Mayer et al. 1995). Empirically, supported by Lau and Sholihin (2005) and L \& M who argue that the use of nonfinancial performance measures in evaluating managers is positively associated with trust, we therefore expect that the use of nonfinancial performance measures will be positively associated with trust in superiors. The following hypothesis is therefore to be tested:

$H_{a 5}:$ The use of nonfinancial measures is associated with interpersonal trust.

\section{Trust and Managerial Performance}

Trust may be classified into individual beliefs and interpersonal trust. Whilst the individual beliefs focus on the competence, responsibility, reliability, and dependability of the trustees, interpersonal trust focuses on reciprocated interpersonal care and concern. However, as first put concern, we conceptualize trust in this study as interpersonal trust. According to McAllister (1995) there are two principal forms of interpersonal trust: (1) cognition-based trust; and (2) affective-based trust. Cognition-based trust is "we choose whom we will trust, in which respects, and under what circumstances, and we base the choice on what we take to be 'good reasons', constituting evidence of trustworthiness" (Lewis and Wiegert 1985: 970). Consolidation between emotional bonds among individuals is affective-based trust (Lewis and Wiegert 1985). McAllister (1995) add that the 
emotional bonds between individuals may base the formation of trust.

Lippit (1982) further argues that trust among people may increase problem solving capability and improve performance. Supporting Lippit (1982), Zand (1997) gives additional suggestions, which in his point of view show that trust successfully built between two people will be highly capable of effectively solving problems, assisting others, contributing performance to team work, and enhancing the quality and implementation capacities of a decision. It is likely that the level of decision quality will be followed by the rate of working performance. Reina and Reina (1999: 8) states that 'directly or indirectly, trust is related to individual, group, and organisational performance'. This gives rise to the hypothesis:

Ha6: Trust is positively associated with performance

\section{Trust and Organizational Commitment}

Drawing on the findings of Ketchand and Strawser (2001), Lau et al. (2008) argue that since subordinates mostly identify with an organization through their supervisors' attitudes, trust in supervisors may be associated with organizational commitment. Thus, subordinates will dedicate similar feelings towards both their superiors and organization, either positive or negative. Put simply, once subordinates act positively (or negatively) towards their superiors, who act on behalf of the organization, they at the same time are also likely to indicate positive (or negative) attitudes and feelings towards their organization. It means that the level of trust in superiors could possibly help to determine subordinates' attitude towards the organization. "This may lead to the subordinates bonding with the organization, and hence, high organizational commitment" (Lau et al. 2008: 126). Consistent with empirical evidence shown by Lau et al. (2008) and Sholihin and Pike (2009) trust in supervisors is positively associated with organizational commitment. We therefore, hypothesize:

Ha7: Trust in superiors is positively related to organizational commitment.

\section{Procedural Fairness and Organizational Commitment}

In 2001, Colquitt et al. produced a metaanalytic review of empirical studies of justice that supports the positive association between procedural justice and organizational commitment which also supported by empirical accounting literature. Such an example is given by Magner and Welker (1994) who found that the fairness of organizational budgeting procedures associates with subordinates' general attitude including organizational commitment. Magner et al. (1995) found that fairness in budgeting systems for subordinates is further simply translated as their capability of understanding and involving themselves in the organization. In this case, psychologically, the more they participate in the budgeting systems and, in contrast, the less they get desirable budgets, surprisingly, the more they feel attached to their superiors and organization. Therefore, based on their findings we may conclude that fairness for subordinates may even vary from one to the next, however, it will stick to one common sense which is participation. Through participating in the systems, subordinates may help themselves in understanding and compromising with their superiors and, most importantly, their organization. Moreover, their findings also advocate the argument that procedural fairness is a significant factor affecting the appearance of trust and organizational 
commitment. Using a sample of managers from UK manufacturing organizations, L \& $\mathrm{M}$ found that procedural fairness is positively associated with organizational commitment. We therefore expect that procedural fairness will be positively associated with organizational commitment. Therefore we hypothesize:

Ha8: Procedural justice is positively associated with organizational commitment.

\section{Research Method}

\section{Data and Sample}

To test the hypotheses, we use data gathered by means of a questionnaire survey. Our samples are managers who were taking their master degree in Master of Management (MM) program, Faculty of Economics and Business (FEB), Universitas Gadjah Mada (UGM).We distributed the questionnaires and requested them to complete when they were in the class of business research method.

Descriptive statistics reveal that our samples are managers with an average age of 30 , have 4 years' experience in their current area of responsibilities, and 3 years in their current position, ranging from top level management ( 9 people), middle level management (35 people), and lower level manage- ment (49 people). They have, on average, 374 employees below their scope of responsibilities. As for the kind of industries, 54 respondents belong to service industries, while the rest are manufacturing, commerce, mining industries, and others. As for their area of responsibilities, most respondents are from marketing department.

\section{Variables and Their Measurement}

\section{Nonfinancial measures}

Whilst L\&M used 15-items, we used 17items in the questionnaire as previously used by Lau and Sholihin (2005). The items were originally developed by Hoque et al. (2001) which were derived from Kaplan and Norton's (1992) three dimensions of nonfinancial measures in the Balanced Scorecard. As the instrument was originally made to measure organizational performance, we use the instruction of Hopwood (1972) since we try to measure managerial performance. We employed the one previously used by Lau and Sholihin (2005) because the instrument was successfully used in the Indonesian context.The 17 nonfinancial measure items can be seen in Table 1 .

Factor analysis was performed to examine whether the 17 nonfinancial items are still consistent with the three nonfinancial measures dimensions suggested by Kaplan and

Table 1. Factor Loadings for Nonfinancial Measures Items

\begin{tabular}{|c|c|c|c|}
\hline Items & $\begin{array}{c}\text { Internal } \\
\text { Business } \\
\text { Process }\end{array}$ & Customer & $\begin{array}{l}\text { Learning } \\
\text { and Growth }\end{array}$ \\
\hline Manufacturing lead time. & 0.736 & & \\
\hline Rate of material scrap loss. & 0.774 & & \\
\hline Percent defective products shipped. & 0.792 & & \\
\hline
\end{tabular}


Table 1 (Continued)

\begin{tabular}{lccc}
\hline Items & $\begin{array}{c}\text { Internal } \\
\text { Business } \\
\text { Process }\end{array}$ & Customer & $\begin{array}{c}\text { Learning } \\
\text { and Growth }\end{array}$ \\
\hline Ratio of good output to total output. & 0.601 & & \\
Number of new patents. & 0.759 & & \\
Number of new product launches. & 0.755 & & \\
Time-to-market new products. & 0.715 & & \\
Market share. & 0.713 & & \\
On-time delivery. & 0.680 & & \\
Survey of customer satisfaction. & 0.635 & & \\
Warranty repair cost. & 0.832 & & \\
Customer response time. & 0.704 & & \\
Cycle time from order to delivery. & 0.745 & & \\
Percent shipments returned due to poor quality. & 0.853 & & 0.644 \\
Labour efficiency variance. & & 0.619 & 7.480 \\
Material efficiency variance. & & & \\
Number of customer complaint. & 8.6934 & 9.612 & \\
Eigenvalue & & & \\
\% variance explained & 50.581 & & \\
\hline
\end{tabular}

Norton (1992). The results reveal there are three factors that have eigenvalue of greater than one, which all items are loaded satisfactorily into each expected perspective (factor loadings of greater than 0.50 ) as presented in Table 1. The cronbach's alpha coefficient for the 17 nonfinancial items was 0.934 . This indicates the high internal consistency of the 17 items.

\section{Managerial performance}

This variable is measured using an instrument developed by Mahoney et al. (1963). The instrument consists of a 9-item 7-point Likert scale and asked respondents to rate the degree of their performance in the area of planning, coordinating, evaluating, investigating, supervising, staffing, negotiating, representing, and overall performance in their or- ganization. This managerial performance measurement instrument is also the one used by $L \& M$.

Consistent with $\mathrm{L} \& \mathrm{M}$, in our analysis we use the overall performance dimension. However, in order to ensure that overall performance is capable of representing the eight dimensions of managerial performance, we regressed the eight dimensions to overall performance. This technique is consistent with prior studies by Brownell (1982), Kren (1992), and Lau et al. (1995) as mentioned in L\&M. The results show the eight dimensions are capable of explaining 67 percent variance of overall performance. This result is beyond the 55 percent benchmark suggested by Mahoney et al. (1963) (L\&M 2008) and prior study by L\&M that only results in 57.7 percent. 


\section{Perception of procedural fairness}

This variable is measured using an instrument developed by McFarlin and Sweeney (1992) and previously used by Lau and Sholihin (2005), L\&M, and Sholihin and Pike (2009). This 4-item 5-point Likert scale asked respondents to rate the fairness of procedures used to (1) evaluate employee performance; (2) determine promotions; (3) communicate performance feedback; (4) determine pay increases. The rotated factor loadings for the four items of procedural fairness range from 0.832 to 0.877 and load on a single factor with eigenvalue of 2.925 that explains 73.136 percent of the variance. The four items have cronbach's alpha of 0.877 . The mean score is 13.09 with standard deviation 3.085 .

\section{Organizational commitment}

This variable is captured using an instrument developed by Mowday et al. (1974). In this 9-item 7-point Likert scale, respondents are required to rate their agreement on various statements, such as: (1) I talk up this organization to my friends as a great organization to work for; (2) I am proud to tell others that I am part of this organization; and (3) This job is my ideal job.

Factor analysis indicates all nine organizational commitment items are loaded satisfactorily on one factor with eigenvalue of 6.228 that explains 69.203 percent of the variance. Factor loadings range from 0.775 to 0.898 . The mean is 46.04 with standard deviation of 10.058. Cronbach's alpha captured at 0.943 .

\section{Interpersonal Trust}

This variable is measured using an instrument developed by Read (1962) and used by Lau and Sholihin (2005) and Sholihin and Pike (2009). This 4-item 5-point Likert scale instrument asked respondents to assess the intensity of (1) their supervisors' actions in taking opportunities that may advance their interest; (2) their freedom to have discussions with their supervisors without worrying their positions; (3) feeling confidence that their supervisors keep them fully and frankly updated concerning issues that may attracts their concerns; and (4) respondents' trust concerning their supervisors' justifiable manner in taking decisions that are against their interests.

A factor analysis was undertaken to ensure the unidimensional nature of the variable trust in supervisors. The results indicate that only one factor with eigenvalue of greater than one was extracted (eigenvalue $=2.804$; total variance explained $=70.112 \%)$. Factor loadings for trust in supervisors loaded satisfactorily from 0.803 to 0.865 . Cronbach's alpha captures at 0.856 with mean 13.32 and standard deviation 3.146 .

\section{Results and Discussions}

To test the hypotheses, this study utilizes Structural Equation Modeling (SEM) using SmartPLS version 2.0. PLS is chosen because of its alternative offer in the estimation approach to traditional SEM as well as its ability in examining small samples of data and because it does not require normality assumptions (Wold 1982; Wold et al. 1987). Further, by utilizing Partial Least Square (PLS), the "researcher may be enabled to represent the constructs of their model as composites based on factor analysis results, with no attempt to create covariance among measured items" (Hair et al. 2006:844). Utilizing SmartPLS 2.0, this study assumes no particular estimated parameters distribution, thus it is based on a non-parametric measurement prediction (Chin 1998). 
Using PLS we are able to measure both measurement and structural model. Measurement model is used to evaluate the validity and reliability of the instrument. Validity is evaluated by examining convergent and discriminant validity from each of the indicators, whereas reliability is examined through evaluating Cronbach's Alpha and composite reliability.Structural model is used to evaluate the goodness of fit of the model. In PLS approach, it is evaluated by examining the variance percentage explained by the $\mathrm{R}^{2}$ value of independent latent variable. The stability of this estimation is evaluated using $t$ test with bootstrapping process.

\section{Measurement Model}

\section{Validity}

The results of measurement model test are shown in Table 2 and Table 3. Table 2 shows the factor loading as well as the cross loading of the variables studied. The results indicate all items load on the expected factor above 0.70 except NF3, NF4, NF6, NF9, NF11, NF12, NF13, and NF15. However, those items have factor loading above 0.50 on the expected factor and none of those items load higher on the unexpected factor. Table 3 reveals that all indicators have AVE value higher than 0.50 . Overall, it can be concluded that the measures are valid both in terms of convergent and discriminant validity and can be used for further analysis (See Hair et al. 2006; and Hulland 2009).

\section{Reliability}

As can be seen in Table 3 the composite reliability and Cronbach's Alpha for all the variables are greater than 0.70 . This means that the instruments used in this study are considerably reliable.

Table 2. Cross Loadings

\begin{tabular}{lccccc}
\hline & MP & NF & OC & PF & T \\
\hline MP9 & $\mathbf{1}$ & 0.1774 & 0.4966 & 0.4545 & 0.3683 \\
NF1 & 0.0964 & $\mathbf{0 . 7 4 3 2}$ & 0.1902 & 0.1564 & 0.1065 \\
NF2 & 0.0442 & $\mathbf{0 . 7 7 1 7}$ & 0.1975 & 0.0533 & 0.0384 \\
NF3 & 0.1565 & $\mathbf{0 . 5 5 8 2}$ & 0.1772 & 0.2068 & 0.1331 \\
NF4 & 0.0856 & $\mathbf{0 . 6 4 3 6}$ & 0.1724 & 0.2004 & 0.1349 \\
NF5 & 0.1191 & $\mathbf{0 . 8 0 0 2}$ & 0.2004 & 0.1517 & 0.1747 \\
NF6 & 0.0955 & $\mathbf{0 . 6 1 4 0}$ & 0.1013 & 0.0624 & 0.0366 \\
NF7 & 0.1041 & $\mathbf{0 . 7 6 0 3}$ & 0.2086 & 0.1065 & 0.1593 \\
NF8 & 0.0328 & $\mathbf{0 . 7 2 2 8}$ & 0.0914 & -0.0171 & 0.1044 \\
NF9 & 0.0599 & $\mathbf{0 . 6 7 7 7}$ & 0.1478 & -0.0751 & 0.0936 \\
NF10 & 0.1893 & $\mathbf{0 . 7 0 7 9}$ & 0.2076 & 0.1115 & 0.2099 \\
NF11 & 0.1167 & $\mathbf{0 . 6 5 0 4}$ & 0.1638 & -0.0159 & 0.1177 \\
NF12 & 0.1641 & $\mathbf{0 . 5 7 9 1}$ & 0.0781 & 0.0312 & 0.0544
\end{tabular}


Table 2 (Continued)

\begin{tabular}{lccccr}
\hline & MP & NF & OC & PF & T \\
\hline NF13 & 0.1657 & $\mathbf{0 . 6 3 0 0}$ & 0.1300 & 0.2124 & 0.1906 \\
NF14 & 0.1668 & $\mathbf{0 . 8 2 4 7}$ & 0.1752 & 0.1778 & 0.1292 \\
NF15 & 0.2243 & $\mathbf{0 . 6 6 8 4}$ & 0.1297 & -0.0388 & -0.0932 \\
NF16 & 0.1353 & $\mathbf{0 . 7 4 3 4}$ & 0.1783 & 0.1526 & 0.137 \\
NF17 & 0.1558 & $\mathbf{0 . 8 4 9 4}$ & 0.1958 & 0.1278 & 0.1928 \\
OC1 & 0.408 & 0.1511 & $\mathbf{0 . 8 0 7 6}$ & 0.3358 & 0.3859 \\
OC2 & 0.4207 & 0.213 & $\mathbf{0 . 8 0 1 7}$ & 0.4198 & 0.4025 \\
OC3 & 0.3957 & 0.2309 & $\mathbf{0 . 7 9 5 9}$ & 0.5464 & 0.4606 \\
OC4 & 0.3304 & 0.2441 & $\mathbf{0 . 8 3 5 2}$ & 0.3434 & 0.3712 \\
OC5 & 0.4102 & 0.1516 & $\mathbf{0 . 8 6 0 1}$ & 0.4078 & 0.4091 \\
OC6 & 0.502 & 0.2234 & $\mathbf{0 . 9 0 3 5}$ & 0.5555 & 0.536 \\
OC7 & 0.397 & 0.1534 & $\mathbf{0 . 7 6 7 6}$ & 0.3046 & 0.313 \\
OC8 & 0.3872 & 0.1918 & $\mathbf{0 . 8 2 4 3}$ & 0.4893 & 0.4985 \\
OC9 & 0.4381 & 0.2485 & $\mathbf{0 . 8 7 8 4}$ & 0.415 & 0.3624 \\
PF1 & 0.365 & 0.1453 & 0.4478 & $\mathbf{0 . 8 3 7 7}$ & 0.4901 \\
PF2 & 0.3583 & 0.0884 & 0.4216 & $\mathbf{0 . 8 7 4 1}$ & 0.5951 \\
PF3 & 0.339 & 0.1804 & 0.3863 & $\mathbf{0 . 8 3 9 7}$ & 0.4473 \\
PF4 & 0.4691 & 0.1849 & 0.5071 & $\mathbf{0 . 8 6 5 1}$ & 0.4533 \\
T1 & 0.1996 & 0.2243 & 0.4111 & 0.455 & $\mathbf{0 . 8 1 4 5}$ \\
T2 & 0.3625 & 0.0633 & 0.432 & 0.4505 & $\mathbf{0 . 8 6 8 3}$ \\
T3 & 0.4097 & 0.2329 & 0.4951 & 0.5753 & $\mathbf{0 . 8 8 2 6}$ \\
T4 & 0.2062 & 0.1106 & 0.3277 & 0.4263 & $\mathbf{0 . 7 7 3 8}$ \\
\hline & & & & & \\
\hline
\end{tabular}




\begin{tabular}{|c|c|c|c|c|c|}
\hline & & $\begin{array}{c}\text { Outer } \\
\text { Loading }\end{array}$ & AVE & $\begin{array}{c}\text { Cronbach's } \\
\text { Alpha }\end{array}$ & $\begin{array}{l}\text { Composite } \\
\text { Reliability }\end{array}$ \\
\hline \multirow[t]{4}{*}{ Procedural Fairness } & PF1 & 0.8377 & 0.7299 & 0.8773 & 0.9153 \\
\hline & PF2 & 0.8741 & & & \\
\hline & PF3 & 0.8397 & & & \\
\hline & PF4 & 0.8651 & & & \\
\hline \multirow[t]{4}{*}{ Trust } & $\mathrm{T} 1$ & 0.8145 & 0.6987 & 0.8576 & 0.9025 \\
\hline & $\mathrm{T} 2$ & 0.8683 & & & \\
\hline & $\mathrm{T} 3$ & 0.8826 & & & \\
\hline & $\mathrm{T} 4$ & 0.7738 & & & \\
\hline Managerial Performance & MP9 & 1.0000 & 1.0000 & 1.0000 & 1.0000 \\
\hline \multirow[t]{9}{*}{ Organizational Commitment } & OC1 & 0.8076 & 0.6914 & 0.9439 & 0.9526 \\
\hline & $\mathrm{OC} 2$ & 0.8017 & & & \\
\hline & OC3 & 0.7959 & & & \\
\hline & $\mathrm{OC} 4$ & 0.8352 & & & \\
\hline & OC5 & 0.8601 & & & \\
\hline & OC6 & 0.9035 & & & \\
\hline & OC7 & 0.7676 & & & \\
\hline & $\mathrm{OC} 8$ & 0.8243 & & & \\
\hline & OC9 & 0.8784 & & & \\
\hline \multirow[t]{10}{*}{ Nonfinancial Measures } & NF1 & 0.7432 & 0.5005 & 0.9372 & 0.9438 \\
\hline & NF2 & 0.7717 & & & \\
\hline & NF3 & 0.5582 & & & \\
\hline & NF4 & 0.6436 & & & \\
\hline & NF5 & 0.8002 & & & \\
\hline & NF6 & 0.6140 & & & \\
\hline & NF7 & 0.7603 & & & \\
\hline & NF8 & 0.7228 & & & \\
\hline & NF9 & 0.6777 & & & \\
\hline & NF10 & 0.7079 & & & \\
\hline
\end{tabular}


Table 3 (Continued)

\begin{tabular}{lllll}
\hline Outer & AVE & $\begin{array}{c}\text { Cronbach's } \\
\text { Alpha }\end{array}$ & $\begin{array}{c}\text { Composite } \\
\text { Reliability }\end{array}$ \\
\hline NF11 & 0.6504 & & \\
NF12 & 0.5791 & & \\
NF13 & 0.6300 & \\
NF14 & 0.8247 & \\
NF15 & 0.6684 & \\
NF16 & 0.7434 & \\
NF17 & 0.8494 & \\
\hline
\end{tabular}

\section{Structural Model}

Recall that the first objective of our study is to test the generalizability of $\mathrm{L} \& \mathrm{M}$ findings. Therefore, firstly we retest L \& M's model using our sample. The results are presented in table 4. The table shows that the use of nonfinancial measures is positively associated with organizational commitment $(r=0.220 ; p<0.05)$. However, the use of nonfinancial measures is not associated with procedural fairness nor managerial performance. This is in contrast to $\mathrm{L} \&$ M's results. Further, the table indicates that procedural fairness is associated organizational commitment $(\mathrm{r}=0.500 ; \mathrm{p}<0.01)$ and managerial performance $(r=0.448 ; \mathrm{p}<0.01)$. Overall, our study partially support L \& M's study.

Having seen that our study partially supports L \& M's study, we then examine our model which is the extension of L \& M's model. Recall, our model includes trust as the potential mediating variable on the relationship between: (1) nonfinancial measures and managerial performance; and (2) organizational commitment and managerial performance. The results are depicted in Table 5.

Table 4. The Results of PLS Using L \& M's Model

\begin{tabular}{lccc}
\hline Path & Coeeficient & t-statistics & p-values \\
\hline NF-->OC & 0.22 & 1.6858 & 0.0467 \\
NF-->PF & 0.1424 & 0.6833 & 0.2476 \\
PF-->OC & 0.5002 & 6.4899 & 0.0000 \\
PF-->MP & 0.4475 & 3.7165 & 0.0001 \\
OC-->MP & 0.3555 & 3.2635 & 0.0006 \\
NF-->MP & 0.1166 & 1.2289 & 0.1103 \\
\hline
\end{tabular}


Table 5. The Results of Structural Model Using Our Model

\begin{tabular}{cccccc}
\hline Hypotheses & Path & Coefficient & t-statistics & p-values & Result \\
\hline Ha1 & NF -> PF & 0.1776 & 1.1981 & 0,1162 & Unsupported \\
Ha2 & PF -> MP & 0.2460 & 2.9378 & 0,0018 & Supported \\
Ha3 & NF -> OC & 0.1278 & 2.4691 & 0,0072 & Supported \\
Ha4 & OC - > MP & 0.3416 & 3.1436 & 0,0010 & Supported \\
Ha5 & NF - > T & 0.1943 & 1.5874 & 0,0570 & Unsupported \\
Ha6 & T -> OC & 0.2923 & 2.6184 & 0,0048 & Supported \\
Ha7 & T -> MP & 0.0528 & 1.3621 & 0,0874 & Unsupported \\
Ha8 & PF -> OC & 0.3296 & 2.9120 & 0,0020 & Supported \\
\hline
\end{tabular}

The table shows that nonfinancial measures are positively associated with organizational commitment and organizational commitment is positively associated with managerial performance. The use of nonfinancial measures, however, is not associated with procedural fairness and trust. The table also indicates that procedural fairness is associated with organizational commitment and managerial performance. Further, it reveals that trust is associated with organizational commitment but not with managerial performance. $\mathrm{R}^{2}$ of our overall model with managerial performance as the ultimate dependent variable is 0.301 .

\section{Conclusions, Limitations, and Suggestions for Future Research}

The objectives of this study are: (1) to examine the generalizability of L \& M's study; and (2) to extend the L \& M's model. L \&M's model argues that the use of nonfinancial measures in managerial performance evalua- tion will result in functional attitudes and behavior. They found that the use of nonfinancial measures is positively associated with procedural fairness and organizational commitment which in turn positively affects managerial performance. Using UK senior managers as their sample, their findings support their hypotheses. Our study, using Indonesian managers, the majority of whom are from medium and lower managerial levels, reveals that nonfinancial measures usage is positively associated with organizational commitment but not with procedural fairness. Whilst our study is unable to support all L \& M's findings, our results are consistent with organizational justice literature that says "a universal concern of justice.... does not mean that all justice effects are necessarily generalisable ..." (Leung 2005: 557). Moreover, Colquitt and Jackson (2006) have shown that fairness judgement is dependent upon context.

Using the extended model which includes trust as the potential mediating variables on the relationship between: (1) nonfi- 
nancial measures use and managerial performance; (2) organizational commitment and managerial performance. Our results, however, do not support the proposed mediating roles of trust.

The study, however, should be interpreted cautiously due to the limitations associated with it. First, as this study uses a survey approach, various inherent limitations associated with such an approach should be acknowledged. Future studies should examine the topic using other approaches, such as experimental study. The second limitation is related to the sampling method. Whilst our study uses convenience sampling approach, future studies can use a random sampling approach.

\section{References}

Angle, H. L., and J. L. Perry. 1981. An empirical assessment of organizational commitment and organizational effectiveness. Administrative Science Quarterly 26 (1): 1-14.

Atkinson, A. A., R. D. Banker, R. S. Kaplan, S. M. Young. 2001. Management accounting. New Jersey: Prentice Hall International, Inc.

Bacon, L. D. 1997. Using AMOS for structural modeling in market research. SPSS White Paper: 1-18.

Becker, H. 1960. Notes on the concept of commitment. American Journal of Sociology: $32-42$.

Chin, W. W. 1998. The partial least squares approach to structural equation modeling. In Marcoulides, G. A. (ed.), Modern Methods for Business Research. London: Lawrence Erlbaum Associates.

Chong, V. K., and I. R. C. Eggleton. 2007. The impact of reliance on incentive-based compensation schemes, information asymmetry and organisational commitment on managerial performance. Management Accounting Research 18 (3): 312-342.

Demir, C. C., B. Sahin, C. K. Teke, C. M. Ucar, and O, Kursun. 2009. Organizational commitment of miliraty physicians. Military Medicine 174 (9): 929-935.

Derfuss, K. 2009. The relationship of budgetary participation and reliance on accounting performance measures with individual-level consequent variables: A meta-analysis. European Accounting Review 18 (2): 203-239.

Folger, R., and Konovsky, M. A. (1989) Effects of procedural and distributive justice on reactions to pay raise decisions. Academy of Management Journal 32 (1): 115.

Hair, J. F., R. L. Tatham, R. E. Anderson, and W. Black. 2006. Multivariate Data Analysis. New Jersey: Prentice Hall.

Hartmann, F. G. H. 2000. The appropriateness of RAPM: Toward the further development of theory. Accounting, Organizations and Society 25 (4-5): 451-482.

Hopwood, A. G. 1972. An empirical study of role of accounting data in performance evaluation. Journal of Accounting Research 10 (Supplement): 156-182.

Hoque, Z., L. Mia, and M. Alam. 2001. Market competition, computer-aided manufacturing and use of multiple performance measures: An empirical study. British Accounting Review 33: 23-45.

Hulland, J. 1999. Use of Partial Least Squares (PLS) in strategic management research: A review of four recent studies. Strategic Management Journal 20 (2): 195 - 204. 
Ittner, C. D., and D. F. Larcker. 1998. Innovations in performance measurement: Trends and research implications. Journal of Management Accounting Research 10: 205-238.

Ittner, C., and D. F. Larcker. 2000. A bigger yardstick for company performance. FT Mastering Management (November): 8-11.

Johnson, H. T., and R. S. Kaplan. 1987. Relevance Lost: The Rise and Fall of Management Accounting. Boston, Mass: Harvard Business School Press.

Kaplan, R. S. 1983. Measuring manufcaturing performance: A new challenge for managerial accounting research. The Accounting Review 58 (4): 686-705.

Kaplan, R. S., and D. P. Norton. 1992. The balanced scorecard: Measures that drive performance. Harvard Business Review (January-February): 71-79.

Kaplan, R. S., and D. P. Norton. 1996. The Balanced Scorecard: Translating Strategy Into Action. Boston, MA: Harvard Business School Publishing.

Ketchand, A. A., and J. R. Strawser. 2001. Multiple dimensions of organizational commitment: Implications for future accounting research. Behavioral Research in Accounting 13: 221 - 251.

Lau, C. M., and A. Moser. 2008. Behavioural effects of nonfinancial performance measures: the role of procedural fairness. Behavioral Research in Accounting 20 (2): 55 - 71.

Lau, C. M., and M. Sholihin. 2005. Financial and nonfinancial performance measures: How do they affect job satisfaction? The British Accounting Review 37 (4): 389-413.

Lau, C. M., K. M. Wong, and I. R. C. Eggleton. 2008. Fairness of performance evaluation procedures and job satisfaction: The role of outcome-based and non-outcome-based effects. Accounting and Business Research 38 (2): 121-135.

Leung, K. 2005. How generalizable are justice effects across culture? In Greenberg, J., and J. A. Colquitt (eds.) Handbook of organizational justice. New Jersey: Lawrence Erlbaum Associates.

Lewis, J. D., and A. Weigert. 1985. Trust as a social reliaty. Social Force (63): 967-985.

Libby, T. 2001. Referent cognitions and budgetary fairness: A research note. Journal of Management Accounting Research 13: 91-106.

Lind, E. A., and T. R. Tyler. 1988. The Social Psychology of Procedural Justice. New York: Plenum Press.

Lindsay, R. M., and S. C. Ehrenberg. 1993. The design of replicated study. The American Statistician 47 (3): 217-228.

Lipe, M. G., and S. E. Salterio. 2000. The balanced scorecard: Judgmental effects of common and unique performance measures. The Accounting Review 75 (3): 283-298.

Lippit, G. L. 1982. Organizational Renewal: A Holistic Approach to Organizational Renewal. Englewood Cliffs, NJ: Prentice Hall.

Little, H. T., N. Magner, R. B. Welker. 2002. The fairness of formal budgetary procedures and their enactment. Group \& Organization Management 27 (2): 209-225.

Lynch, R. L., and K. F. Cross. 1991. Measure Up. London, U.K.: Blackwell Publishers.

Mahoney, T. A., T. H. Jerdee, and S. J. Carrol. 1963. Development of Managerial Performance: A Research Approach. Cincinnati: South Western Publishing.

Mathieu, J. E., and C. D. M. Zaja. 1990. A review and meta-analysis of the antecedents, correlates, and consequences of organizational commitment. Psychological Bulletin 108 (2): 171-194. 
Mayer, R. C., J. H. Davis, and F. D. Schoorman. 1995. An integrative model of organizational trust. The Academy of Management Review 20 (3): 709-734.

McAllister, D. J. 1995. Affect- and cognition-based trust as foundations for interpersonal cooperation in organizations. Academy of Management Journal 38 (1): 24 -58.

McFarlin, D. B., and P. D. Sweeney. 1992. Distributive and procedural justice as predictors of satisfaction with personal and organizational outcomes. Academy of Management Journal 35 (3): 626-637.

Merchant, K. A. 2006. Measuring general managers' performances: Market, accounting and combination-of-measures systems. Accounting, Auditing \& Accountability Journal 19 (6): 893 - 917.

Meyer, J. P., N. J. Allen, and I. R. Gellatly. 1990. Affective and continuance commitment to the organization: Evaluation of measures and analysis of concurrent and time-lagged relations. Journal of Applied Psychology 75 (6): 710 - 720.

Noeverman, J., B. A. S. Koene, and R. Williams. 2005. Construct measurement of evaluative style: A review and proposal. Qualitative Research in Accounting \& Management 2 (1): 77-107.

Nouri, H., and R. J. Parker. 1996. The effect of organizational commitment on the relation between budgetary participation and budgetary slack. Behavioral Research in Accounting 8.

Nouri, H., and R. J. Parker. 1998. The relationship between budget participation and job performance: The roles of budget adequacy and organizational commitment. Accounting, Organizations and Society 23 (5-6): 467-483.

Otley, D. T. 1978. Budget use and managerial performance. Journal of Accounting Research 16 (1): 122-149.

Porter, L. W., and E. E. Lawler. 1968. Managerial Attitudes and Performance. Illinois: Richard D. Irwin.

Porter, L. W., R. M. Steers, R. T. Mowday, and P. V. Boulian. 1974. Organizational commitment, job satisfaction, and turnover among psychiatric technicians. Journal of Applied Psychology 59 (5): 603-609.

Randall, D. M. 1990. The consequences of organizational commitment: Methodological investigation. Journal of Organizational Behavior 11 (5): 361-378.

Read, W. H. 1962. Upward communication industrial hierarchies. Human Relations 15: 3-15.

Reina, D. S., and M. J. Reina. 1999. Trust and Betrayal in the Workplace: Building Effective Relationships in Your Organization. San Francisco: Berrett-Koehler Publishers, Inc.

Ross, A. 1994. Trust as a moderator of the effect of performance evaluation style on job-related tension: A research note. Accounting, Organizations and Society 19 (7): 629-635.

Sholihin, M., and R. Pike. 2009. Fairness in performance evaluation and its behavioral consequences. Accounting and Business Research 39 (7): 1-17.

Sholihin, M., A. Na'im, and C. M. Lau. 2004. The effects of multiple measures-based performance evaluation on managers' performance: The role of procedural fairness and interpersonal trust. In Epstein, M. J., and J-F. Manzoni (eds.), Studies in Managerial and Financial Accounting 14. Elsevier.

Supriyadi. 2010. The moderating effect of procedural justice on the effectiveness of the Balanced Scorecard in improving managerial performance trough organizational commitment. Gadjab Mada International Journal of Business 12 (3): 415-434.

Thibaut, J. and J. Walker. 1975. Procedural Justice: A Psychological Analysis. New York: John Wiley.

Vaivio, J. 1999. Exploring a "non-financial" management accounting change. Management Accounting Research 10 (2): 409-437. 
Vroom, V. H. 1964. Work and Motivation. New York: John Wiley \& Sons, Inc.

Wentzel, K. 2002. The influence of fairness perceptions and goal commitment on managers' performance in a budget setting. Behavioral Research in Accounting 14:247-271.

Whitener, E. M., S. E. Brodt, M. A. Korsgaard, and J. M. Werner. 1998) Managers as initiators of trust: An exchange relationship framework for understanding managerial trustworthy behavior. The Academy of Management Review 23 (3): 513-530.

Wold, H. 1985. Partial Least Squares. In Kotz, S., and N. L. Johnson (eds). Encyclopedia of Statistical Sciences 8: 587-599. New York: Wiley.

Wold, S., P. Geladi, K. Esbensen, and J. Öhman. 1987. Multiway principal components and PLS analysis. Journal of Chemometrics 1 (1): 41-56.

Zand, D. E. 1997. The Leadership Triad: Knowledge, Trust, and Power. New York: Oxford University Press. 